\title{
Extracellular adenosine 5 '-triphosphate concentrations changes in rat spinal cord associated with the activation of urinary bladder afferents. A microdialysis study
}

\author{
Variação da concentração extracelular de 5'-trifosfato de adenosina na medula espinal de rata \\ associadas a fibras aferentes vesicais. Um estudo com microdiálise
}

\author{
Jeová Nina Rocha ${ }^{1}$
}

\begin{abstract}
Objective: To determine adenosine $5^{\prime}$-triphosphate levels in the interstice of spinal cord $\mathrm{L}_{6}-\mathrm{S}_{1}$ segment, under basal conditions or during mechanical and chemical activation of urinary bladder afferents. Methods: A microdialysis probe was transversally implanted in the dorsal half of spinal cord $\mathrm{L}_{6}-\mathrm{S}_{1}$ segment in female rats. Microdialysate was collected at 15 minutes intervals during 135 minutes, in anesthetized animals. Adenosine 5 'triphosphate concentrations were determined with a bioluminescent assay. In one group of animals $(n=7)$ microdialysate samples were obtained with an empty bladder during a 10-minutes bladder distension to 20 or $40 \mathrm{cmH}_{2} \mathrm{O}$ with either saline, saline with acetic acid or saline with capsaicin. In another group of animals $(n=6)$ bladder distention was performed and the microdialysis solution contained the ectonucleotidase inhibitor ARL 67156. Results: Basal extracellular adenosine triphosphate levels were $110.9 \pm 35.34 \mathrm{fmol} / 15$ minutes, (mean \pm SEM, $n=13$ ), and bladder distention was associated with a significant increase in adenosine $5^{\prime}$-triphosphate levels which was not observed after bladder distention with saline solution containing capsaicin $(10 \mu \mathrm{M})$. Microdialysis with solution containing ARL $67156(1 \mathrm{mM})$ was associated with significantly higher extracellular adenosine $5^{\prime}$-triphosphate levels and no further increase in adenosine 5 '-triphosphate was observed during bladder distension. Conclusion: Adenosine $5^{\prime}$-triphosphate was present in the interstice of $\mathrm{L}_{6}-\mathrm{S}_{1}$ spinal cord segments, was degraded by ectonucleotidase, and its concentration increased following the activation of bladder mechanosensitive but not of the chemosensitive afferents fibers. Adenosine $5^{\prime}$-triphosphate may originate either from the central endings of bladder mechanosensitive primary afferent neurons, or most likely from intrinsic spinal neurons, or glial cells and its release appears to be modulated by capsaicin activated bladder primary afferent or by adenosine 5 -triphosphate itself.
\end{abstract}

Keywords: Adenosine triphosphate; Microdialysis; Visceral afferents; Spinal cord

\section{RESUMO}

Objetivo: Determinar as concentrações extracelulares do $5^{\prime}$-trifosfato de adenosina no interstício dos segmentos medulares $L_{6}-S_{1}$, em condições basais ou durante a ativação mecânica e química das fibras aferentes vesicais. Métodos: Um cateter de microdiálise foi implantado no sentido transversal na parte dorsal da medula espinal, entre os segmentos $L_{6}-S_{1}$ de ratas. 0 microdialisado foi coletado em intervalos de 15 minutos, durante 135 minutos, com os animais anestesiados. A concentração de 5 'trifosfato de adenosina nas amostras foi determinada mediante ensaio de bioluminescência. Em um grupo de animais $(n=7)$, as amostras de microdialisado foram obtidas com a bexiga vazia, com distensão da bexiga para volume de 20 ou $40 \mathrm{cmH}_{2} \mathrm{O}$, com solução salina, solução salina com ácido acético, ou solução salina com capsaicina. Em outro grupo $(n=6)$, foi realizada com a bexiga distendida, e a solução para microdiálise continha 0 inibidor de ectonucleotidase ARL 67156. Resultados: Os níveis extracelulares de trifosfato de adenosina no início do estudo foram 110,9 $\pm 35,36 \mathrm{fmol} / 15$ minutos (média $\pm E P M, n=13$ ), e a distensão da bexiga causou um aumento nos níveis de $5^{\prime}$-trifosfato de adenosina, o que não foi observado após a distensão da bexiga com solução salina contendo capsaicina $(10 \mu \mathrm{M})$. A microdiálise com solução contendo ARL 67156 (1mM) foi associada com significante aumento dos níveis de trifosfato de adenosina extracelular, e nenhum aumento do trifosfato de adenosina foi observado durante a distensão da bexiga. Conclusão: $05^{5}$-trifosfato de adenosina está presente no interstício do segmento $\mathrm{L}_{6}-\mathrm{S}_{1}$ da medula espinal, é degradado por ectonucleotidases, e sua concentração aumentou com a ativação das fibras aferentes mecanossensíveis da bexiga,

\footnotetext{
${ }^{1}$ Faculdade de Medicina de Ribeirão Preto, Universidade de São Paulo, Ribeirão Preto, SP, Brazil. Corresponding author: Jeová Nina Rocha - Avenida Bandeirantes s/n - Monte Alegre - Zip code: 14048-900 - Ribeirão Preto, SP, Brazil - Phone: (55 16) $3602-3302$ - E-mail: jeova_rocha@yahoo.com Received on: June 22, 2016 - Accepted on: Oct 25, 2016
} 
mas não das quimiossensíveis. 0 5'-trifosfato de adenosina pode ter sido liberado das terminações centrais dos neurônios aferentes primários mecanossensíveis ou, mais provavelmente, de neurônios espinais intrínsecos, ou ainda de células gliais. Sua liberação parece ser modulada por fibras aferentes primárias da bexiga ativadas pela capsaicina ou pelo próprio 5'-trifosfato de adenosina.

Descritores: Trifosfato de adenosina; Microdiálise; Fibras aferentes; Medula espinal

\section{INTRODUCTION}

Adenosine 5'-triphosphate (ATP) was detected in dorsal ganglia extracts more than 50 years ago. ${ }^{(1)} \mathrm{A}$ few years later, it was observed that antidromic stimulation of primary afferent fibers caused an increase in extracellular ATP levels in tissues innervated by the stimulated afferent fibers. ${ }^{(2)}$ Since then, accumulated evidence have indicated that ATP, besides its established role as an intracellular energy source, can also act as an extra- and intercellular messenger released by a variety of cells, including neurons in the central and peripheral nervous system. ${ }^{(3,4)}$

Adenosine 5'-triphosphate has been also proposed to be a neurotransmitter released by the central endings of some primary afferent neurons, ${ }^{(5,6)}$ however, most evidence that support this proposal is indirect. For example, electrophysiological studies (patch-clamp) on spinal cord slices showed that two purported $\mathrm{P}_{2}$ receptor selective antagonists [pyridoxalphosphate-6-azophenyl$2^{\prime}, 4^{\prime}$-disulphonic acid (PPADS) and suramin] decreased, whereas the ectonucleotidase inhibitor (ARL 67156) increased the amplitude of lamina $\mathrm{V}$ neurons excitatory postsynaptic currents (EPSC), evoked by dorsal root stimulation. ${ }^{(6)}$ In addition, studies in vitro, with primary cultures of neonate rat dorsal horn neurons (laminae I-III), showed that postsynaptic currents were reduced by purinergic receptor antagonists. ${ }^{(7)}$ Synaptosomes prepared from spinal dorsal horns release ATP when depolarized with K. ${ }^{(8)}$ Capsaicin pre-treatment of the animals did not alter the amount of ATP released by synaptosomes. Since the quantity of ATP released by spinal cord dorsal horn synaptosomes was only partially reduced by dorsal rhizotomy, it was proposed that ATP originated mainly from capsaicin-insensitive primary afferents fibers (A $\beta$ e $\mathrm{A} \delta$ ), as well as from spinal cord intrinsic neurons. ${ }^{(8,9)}$ In addition, by using intrathecal administration of novel and selective $\mathrm{P}_{2} \mathrm{X}$ antagonists, Kaan et al., suggested that spinal purinergic receptors may regulate afferent signals coming from the bladder. ${ }^{(10)}$

Early experiments in mice lacking the expression of $\mathrm{P}_{2} \mathrm{X}_{3}$ receptors, as well as the use of selective $\mathrm{P}_{2} \mathrm{X}$ antagonists, suggested that peripheral $\mathrm{P}_{2} \mathrm{X}_{1}$ and $\mathrm{P}_{2} \mathrm{X}_{3}$ receptors, at the bladder level, are involved in the micturition reflex. ${ }^{(11-14)}$ More recently, it has been shown that ATP is released by the urothelium to activate purinergic receptors present in the peripheral endings of bladder primary afferents. ${ }^{(15)}$ However, recent experiments conducted in genetically engineered mice that do not express $\mathrm{P}_{2} \mathrm{X}_{2}$ or $\mathrm{P}_{2} \mathrm{X}_{3}$ receptors showed that these receptors are not essential for the normal micturition reflex. ${ }^{(16)}$

Whether ATP is released at the spinal level in response to afferent impulses coming from the bladder, and whether such ATP is involved in the integration of the micturition reflex has not been directly investigated.

\section{OBJECTIVE}

To determine adenosine 5'-triphosphate levels in the interstice of spinal cord $\mathrm{L}_{6}-\mathrm{S}_{1}$ segment under basal conditions or during mechanical and chemical activation of urinary bladder afferents.

\section{METHODS}

Female rats, Sprague Dawley, weighing 230-260g, were used in these experiments. All experimental procedures were approved by the Committee of Ethics in Animal Experimentation of the Faculdade de Medicina de Ribeirão Preto da Universidade de São Paulo, approval number 013/2014-1.

On the day before performing microdialysis, the rats were anesthetized with isoflurane (isoflurane $3-4 \%$ for induction and $1-2 \%$ maintenance dose during the surgery) and ventilated with $100 \%$ oxygen. After hair-clipping and antisepsis using betadine solution, a dorsal median surgical incision extending from $\mathrm{T}_{13}$ to $\mathrm{L}_{5}$ vertebrae was performed. The procedure to implant the microdialysis probe was conducted as previously described. ${ }^{(17)}$ Briefly, using a dental drill (with a $300 \mu \mathrm{m}$ diameter steel burr), a small hole was made in both lamina of $\mathrm{L}_{2}$ vertebra. After that, a tubular fiber $(200 \mu \mathrm{m}$ diameter) $6.0 \mathrm{~cm}$ in length, coated with a thin layer epoxy (except for a $2 \mathrm{~mm}$ middle region that remained uncoated constituting the effective zone for microdialysis) was introduced through these holes, in order to position it in the interstice of $\mathrm{L}_{6}-\mathrm{S}_{1}$ spinal cord segment boundary to dialyze the dorsal horn and the dorsal commissure. The probe was fixed with cyanoacrylate and epoxy glue and its ends were attached to polyethylene catheters (PE-20), which were exteriorized in the dorsal cervical region through a subcutaneous tunnel. The cannulae were filled with $10 \%$ heparin and sealed by electrocauterium. Immediately after the surgery, all animals were injected 
with ampicillin $(100 \mathrm{mg} / \mathrm{kg}$, intramuscular) and placed in individual cages with food and water ad libitum.

\section{Microdialysis experiments}

The animals were anesthetized with urethane $(1 \mathrm{~g} / \mathrm{kg}$, subcutaneously). A catheter (PE-10 Clay Adams, Nova Jersey, USA) was introduced into the right femoral vein for the continuous infusion of saline solution containing $5 \%$ glucose $(5 \mathrm{~mL} /$ minute $)$. A polyethylene (PE-60) catheter was introduced into the bladder through the urethra, and fixed to the urethral meatus in order to monitor intravesical pressure under isovolumetric conditions.

Fluorinated ethylene propylene (FEP) cannulae previously perfused with $30 \%$ ethanol (30 to 40 minutes), and washed with Milli-Q ultrapure water, for 20 minutes, were connected to the PE-20 cannulae in order to perfuse the microdialysis probe (flow rate of $5 \mu \mathrm{L} /$ minute), using microdialysis pump (model CMA-102, CMA, Sweden), with Krebs' solution (mM: $\mathrm{NaCl} 113$; $\mathrm{KCl} 4.7 ; \mathrm{CaCl}_{2} 2.5 ; \mathrm{MgSO}_{4} 1.2 ; \mathrm{NaHCO}_{3} 2.5 ; \mathrm{KH}_{2} \mathrm{PO}_{4}$ 1.2 and d-glucose 11.5 ) saturated with $95 \% \mathrm{O}_{2} / 5 \% \mathrm{CO}_{2}$. The bladder was distended to 20 or $40 \mathrm{cmH}_{2} \mathrm{O}$ for 10 minutes with $0.9 \%$ saline or with $0.9 \%$ saline solution containing $0.1 \%$ acetic acid, or with $0.9 \%$ saline containing capsaicin $(10 \mu \mathrm{m})$.

In a group of animals $(n=6), 1 \mathrm{mM}$ of the ectonucleotidase inhibitor 6-N, N-diethyl-D- $\beta-\gamma-$ dibromomethylene-ATP (ARL 67156) was added to the dialyzing Krebs solution, 90 minutes after initiating the microdialysis. After adding the ARL 67156, microdialysis was continued for another 135 minutes. In all experiments, after 30 to 40 minutes of equilibration period, the microdialysate was collected in 15 minutes samples $(75 \mu \mathrm{L})$, with a microfraction collector (CMA142). Samples were kept on ice until ATP determination, which was performed immediately after finishing the microdialysis.

\section{Determination of adenosine 5'-triphosphate}

Adenosine 5'-triphosphate concentrations in the microdialysis fractions were determined in triplicates using an ATP bioluminescent assay kit (Sigma; FL-AA, MO, USA); luminescence was measured in a luminometer (Turner, TD 20/20, Sunnyvale, CA, USA). The standard curve was constructed employing disodium ATP (Sigma) dissolved in the Krebs' solution.

\section{Histology}

At the end of the microdialysis procedure, the animals received an overdose of urethane and were immediately perfused, via an intracardiac needle, with $150 \mathrm{~mL}$ ice-cold saline, followed by 300 to $350 \mathrm{~mL}$ of $4 \%$ paraformaldehyde in phosphate buffered saline (PBS). The spinal cord was then dissected and a segment containing the lumbosacral region was post-fixed in the same fixative $\left(4^{\circ} \mathrm{C}, 24\right.$ hours $)$. The spinal cord segment was embedded in paraffin and $10 \mu \mathrm{m}$ transverse sections were obtained with a microtome and stained with hematoxylin-eosin to identify the position of the probe.

\section{Statistical analysis}

Adenosine 5'-triphosphate values are expressed in percentage of control values and plotted as mean \pm SEM. The statistical significance was determined by the Student's $t$ test for paired samples. Statistical significance was established at $\mathrm{p}<0.05$.

\section{Reagents and drugs}

Urethane, ARL 67156, ATP, acetic acid and all the constituents of the Krebs' solution were purchased from the Sigma Chemical Co.; capsaicin was purchased from Tocris Cookson Inc.; ampicillin was purchased from Bayer.

\section{RESULTS}

Correct probe position (100 to $150 \mu \mathrm{m}$ dorsal to the central canal) was confirmed histologically in 13 of 42 operated animals. Figure 1 shows a representative spinal cord cross section of an animal in whom the probe was considered correctly positioned. The data described and analyzed in these results correspond only

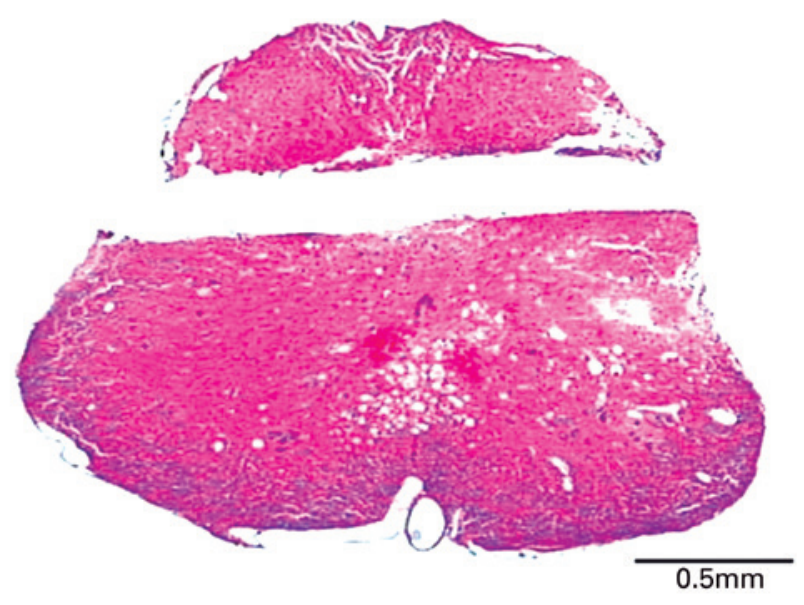

Figure 1. Microphotography of a representative spinal cord cross section $(10 \mu \mathrm{m})$ stained with hematoxylin-eosin showing a correctly positioned microdialysis probe. The absence of the spinal cord tissue (unstained groove) corresponds to the track where the probe was implanted 
to those 13 animals in which the probe was documented to be correctly positioned.

In the animals with the non-distended bladders (basal conditions), the amount of ATP accumulated in the microdialysate during the 15 minutes sampling period was $110.9 \pm 35.34 \mathrm{fmol}(n=13)$. When the bladder was distended for 10 minutes, with saline solution to about $20 \mathrm{cmH}_{2} \mathrm{O}$, the amount of ATP in the microdialysate increased significantly and in a reproducible manner this increase was transient and returned to the predistention values after the distension was removed (Figure 2). The increase in ATP was slightly greater, although not statistically significant, when the bladder was distended with saline solution to non-physiological pressure $\left(40 \mathrm{cmH}_{2} 0\right)$ (Figure 2). Interestingly, when the bladder was distended to $20 \mathrm{cmH}_{2} \mathrm{O}$ with saline solution containing either acetic acid $(0.1 \%)$ or capsaicin $(10 \mu \mathrm{m})$, the amount of ATP in the microdialysate was not higher than that observed when distending the urinary bladder with saline solution alone. Most intriguing, after the bladder had been distended with saline solution containing capsaicin, ATP levels in the microdialysate failed to increase during distention of the urinary bladder with saline alone (Figure 2).

The amount of ATP in the microdialysate increased significantly when ARL 67156 was added to the dialysing solution. ATP levels remained elevated in the continuous presence of ARL and, surprisingly, a 10-minutes bladder distension, with saline solution to either 20 or $40 \mathrm{cmH}_{2} \mathrm{O}$, was not associated with any further increase of ATP in the microdialysate (Figure 3).

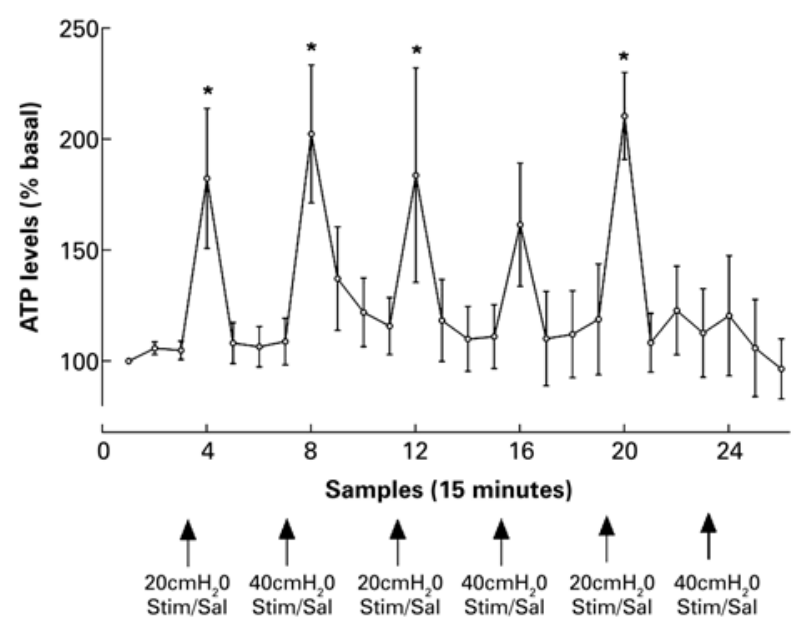

ATP: adenosine 5'-triphosphate; Stim: stimulation; Sal: saline; AA: acetic acid: Caps: capsaicin.

Figure 2. Mean \pm SEM adenosine 5 '-triphosphate levels in successive microdialysate samples, expressed as percentage of basal values during periods of non-distended bladder, and of bladder distended to 20 or $40 \mathrm{cmH}_{2} \mathrm{O}$ with saline solution, or with saline solution containing either acetic acid $(0.1 \%)$ or capsaicin $10 \mu \mathrm{m}, \mathrm{n}=7 ;{ }^{*}=\mathrm{p}<0.05$ compared with preceding value

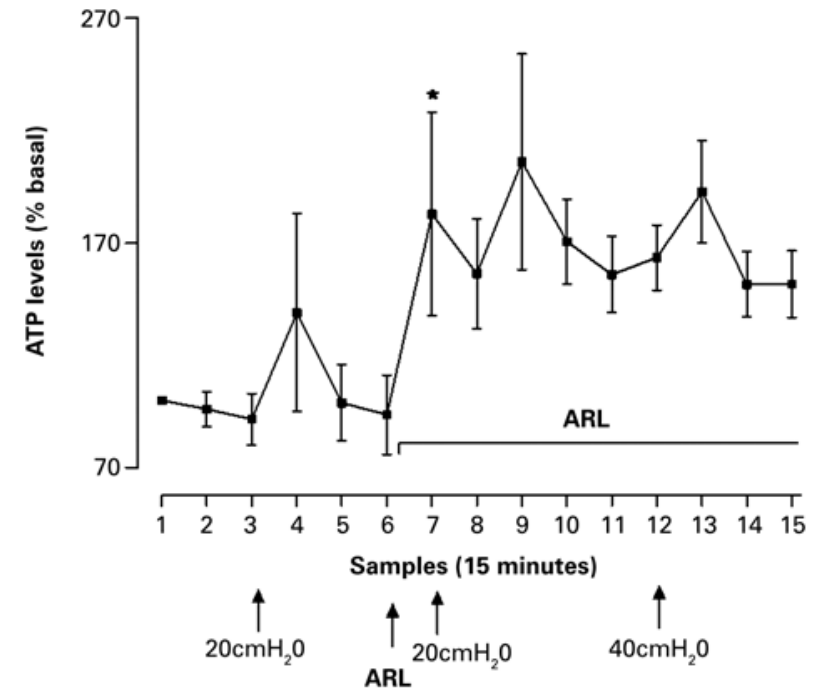

ATP: adenosine 5'-triphosphate.

Figure 3. Mean \pm SEM adenosine 5 '-triphosphate levels in successive microdialysate samples ( $75 \mu \mathrm{L}$, collected in 15 minutes), expressed as percentage of basal values. Following sample 6, ARL 67156 was added to the dialyzing Krebs' solution $[(n=6)-(p<0.05)]$ compared with preceding value

\section{DISCUSSION}

The results of the present study using in vivo spinal cord microdialysis show, for the first time, that ATP is present in the dorsal horn extracellular fluid of rat $\mathrm{L}_{6}-\mathrm{S}_{1}$ spinal cord segments in the absence of bladder distention, suggesting that it is released tonically in this segment of the spinal cord. Considering that the permeable portion of the probe was $2 \mathrm{~mm}$, the dialysated area included mainly both dorsal horns as well as the dorsal gray commissure, and given that the segment $\mathrm{L}_{6}-\mathrm{S}_{1}$ receives input from mechanosensitive afferent fibers innervating the urinary bladder, it is not unlikely that part of the ATP found in the extracellular fluid in the absence of bladder stimulation is released in response to inputs from "spontaneous" active bladder mechanosensitive afferent fibers described previously. ${ }^{(18)}$

In addition, the present results also showed for the first time that a physiological distension of the bladder (intravesical pressure of about $20 \mathrm{cmH}_{2} \mathrm{O}$ ) is associated with an increase in extracellular ATP in the dorsal half of $\mathrm{L}_{6}-\mathrm{S}_{1}$ spinal segment. The observed increase is substantially less than that reported for ATP release in the brainstem chemosensitive area induced by hypercapnia, ${ }^{(19)}$ or in the nucleus tractus solitarii (NTS) following activation of pulmonary stretch receptors ${ }^{(20)}$ using microelectrode biosensors. It is likely that this increase in extracellular ATP results from its release by intrinsic spinal neurons that were activated by the central endings of bladder mechanosensitive afferents. This interpretation is consistent with data showing 
that dorsal horn intrinsic neurons in culture release $\operatorname{ATP}^{(7)}$ as well as with a recent report showing that ATP is released by intrinsic dorsal horn neurons in a vesicular nucleotide transporter (VNUT)-dependent manner. ${ }^{(21)}$ Alternatively, ATP could also originate from dorsal horn glial cells, since these cells can release ATP in response to glutamate. ${ }^{(22)}$ It is worth noting that glutamate has been proposed as the neurotransmitter released by mechanosensitive bladder primary afferents in the dorsal horn. ${ }^{(23,24)}$

Another important observation of this study was the fact that the increase in dorsal horn extracellular ATP, when the bladder was distended with saline solution containing acetic acid or capsaicin, well known activators of chemosensitive afferent fibers in the urinary bladder, was not greater than the one caused by the bladder distension with saline alone. This observation would indicate that the central endings of bladder chemosensitive primary neurons neither release ATP nor activate intrinsic spinal cord cells to release ATP. This interpretation is consistent with previous studies showing that the amount of ATP released by synaptosomes prepared from the dorsal horn was not diminished by the pre-treatment with capsaicin. ${ }^{(8)}$ These findings apparently conflict with the postulated role of ATP as a mediator in primary afferent central endings and dorsal horn neurons synapse; ${ }^{(25)}$ however, more recent studies have shown that ATP does not mediate fast synaptic transmission between dorsal ganglia neurons and dorsal horn neurons at spinal cord lumbar segments. ${ }^{23,26)}$

Perhaps the most intriguing observation of the present study was the fact that bladder distension with saline solution, subsequent to the distension with saline solution containing capsaicin $(10 \mu \mathrm{m})$, was not associated with an increase in dorsal horn extracellular ATP levels. The simplest interpretation of this observation is that neurotransmitters released by the central terminals of capsaicin-sensitive primary afferent neurons (CSPANs) innervating the bladder, which were activated by capsaicin, exert a direct or indirect inhibitory influence on the intrinsic spinal cells that release ATP in the dorsal horn in response to inputs from mechanosensitive primary afferents.

Finally, the present findings indicate also that ATP itself could be involved in an auto-inhibitory control of its release since, after adding the ATPase inhibitor ARL 67156 to the dialyzing solution, which raised extracellular ATP levels, bladder distensions were not associated with further increases in ATP in the dorsal horn interstice. The fact that during microdialysis containing ARL 67156 ATP levels increased is consistent with the description of ectonucleotidases in the dorsal horn lumbar segments. ${ }^{(27)}$ This auto-inhibitory control could be exerted directly on the spinal cells (neuron or glial) that release ATP, or alternatively by an indirect action on spinal interneurons evoking the release of inhibitory neurotransmitters, such as GABA and glycine as shown previously. ${ }^{(28,29)}$

\section{CONCLUSION}

This study shows for the first time, using microdialysis in vivo, that the activation of bladder mechanosensitive afferent fibers caused an increase in extracellular adenosine 5'-triphosphate concentration in the dorsal horn of $\mathrm{L}_{6}-\mathrm{S}_{1}$ spinal cord segment. Whether this increase results from adenosine 5'-triphosphate released by intrinsic spinal neurons, glial cells or both, in response to synaptic input from primary afferent mechanosensitive fibers remains to be investigated. Furthermore, these findings also indicate that adenosine 5 -triphosphate release appears to be modulated by adenosine 5'-triphosphate itself and by capsaicinsensitive primary afferent neurons activity. Finally, although further work is needed to elucidate the role of adenosine 5'-triphosphate released in the dorsal horn in modulating the micturition reflex in physiological and pathophysiological conditions, it is conceivable that spinal dorsal horn purinergic neurotransmission, activated by bladder distention, could constitute a potential pharmacotherapeutic target for clinically relevant alterations in the micturition reflex.

\section{ACKNOWLEDGMENTS}

The author would like to thank Dr. Gustavo Ballejo, Associate Professor, Department of Pharmacology, Faculdade de Medicina de Ribeirão Preto da Universidade de São Paulo, for his helpful collaboration and for his critical reading of this paper.

\section{REFERENCES}

1. Holton FA, Holton P. The capillary dilator in dry powders of spinal roots; a possible role for adenosine triphosphate in chemical transmission from nerve endings. J Physiol. 1954;126(1):124-40

2. Holton P. The liberation of adenosine triphosphate on antidromic stimulation of sensory nerves. J Physiol. 1959;145(3):494-504.

3. Khakh BS, North RA. Neuromodulation by extracellular ATP and P2X receptors in the CNS. Neuron. 2012;76(1):51-69. Review.

4. Burnstock G. An introduction to the roles of purinergic signaling in neurodegeneration, neuroprotection and neuroregeneration. Neuropharmacology. 2016;104:4-17. Review.

5. Salter MW, De Koninck Y, Henry JL. Physiological for adenosine and ATP in synaptic transmission in the spinal dorsal. Prog Neurobiol. 1993;41(2):125-56 Review. 
6. Nakatsuka T, Gu JG. P2X purinoceptors and sensory transmission. Pflugers Arch. 2006;452(5):598-607. Review.

7. Jo YW, Schlichter R. Synaptic co-release of ATP and GABA in cultured spinal neuron. Nat Neurosci. 1999;2(3):241-5.

8. Sawynok J, Dowie JW, Reid AR, Cahil CM, White TD. ATP release from dorsal spinal cord synaptosomes: characterization and neuronal origin. Brain Res. 1993;610(1):32-8.

9. Vulchanova L, Arvidsson U, Riedl MS, Wang J, Buell G, Surprenant A, et al. Differential distribution of two ATP-gated ion channels (P2X receptors) determined by immunocytochemistry. Proc Natl Acad Sci USA. 1996;93(15):8063-7.

10. Kaan TK, Yip PK, Grist J, Cefalu JS, Nunn PA, Ford AP, et al. Endogenous purinergic control of bladder activity via presynaptic P2X3 and P2X2/3 receptors in the spinal cord. J Neurosci. 2010;30(12):4503-7.

11. Cockayne DA, Hamilton SG, Zhu OM, Dunn PM, Zhong Y, Novakovic S, et al. Urinary bladder hyporeflexia and reduced pain-related behaviour in P2X3deficient mice. Nature. 2000;407(6807):1011-5.

12. Cockayne DA, Dunn PM, Zhong Y, Rong W, Hamilton SG, Knight GE, et al. P2X2 knockout mice and P2X2/P2X3 double knockout mice reveal a role for the P2X2 receptor subunit in mediating multiple sensory effects of ATP. $J$ Physiol. 2005;567(Pt 2):621-39.

13. Vlaskovska M, Kasabov L, Rong W, Bodin P, Bardini M, Cockayne DA, et al. P2X3 knockout mice reveal a major sensory role for urothelially released ATP. J Neurosci. 2001;21(15):5670-7.

14. King BF, Knowles ID, Burnstock G, Ramage AG. Investigation of the effects of $P 2$ purinoceptor ligands on the micturition reflex in female urethaneanaesthetized rats. Br J Pharmacol. 2004;142(3):519-30.

15. Nakagomi H, Yoshiyama M, Mochizuki T, Miyamoto T, Komatsu R, Imura Y, et al. Urothelial ATP exocytosis: regulation of bladder compliance in the urine storage phase. Sci Rep. 2016;6:29761.

16. Takezawa K, Kondo M, Kiuchi H, Ueda N, Soda T, Fukuhara S, et al. Authentic role of ATP signaling in micturition reflex. Sci Rep. 2016;6:19585.

17. Rocha JN, Ballejo G. Nitric oxide metabolites in the lumbosacral spinal cord interstice and cerebrospinal fluid in female rats with acute cyclophosphamideinduced cystitis. An in vivo microdialysis study. einstein (São Paulo). 2013; 11(1):88-94. Erratum in: einstein (São Paulo). 2013;11(2):262. Oliveira, Gustavo B [corrected to Ballejo, Gustavo].
18. Su X, Sengupta JN, Gebhart GF. Effects of opioids on mechanosensitive pelvic nerve afferent fibers innervating the urinary bladder of the rat. J Neurophysiol. 1997;77(3):1566-80

19. Gourine AV. On the peripheral and central chemoreception and control of breathing: an emerging role of ATP. J Physiol. 2005;568(Pt 3):715-24. Review.

20. Gourine AV, Dale N, Korsak A, Llaudet E, Tian F, Huckstepp R, et al. Release of ATP and glutamate in the nucleus tractus solitarii mediate pulmonary stretch receptor (Breuer-Hering) reflex pathway. J Physiol. 2008;586(16):3963-78.

21. Masuda T, Ozono Y, Mikuriya S, Kohro Y, Tozaki-Saitoh H, Iwatsuki K, et al. Dorsal horn neurons release extracellular ATP in a VNUT-dependent manner that underlies neuropathic pain. Nat Commun. 2016;7:12529.

22. Zhang JM, Wang HK, Ye CQ, Ge W, Chen Y, Jiang ZL, et al. ATP released by astrocytes mediates glutamatergic activity-dependent heterosynaptic suppression. Neuron. 2003;40(5):971-82.

23. Gu JG, MacDermott AB. Activation of ATP P2X receptors elicits glutamate release from sensory neuron synapses. Nature. 1997;389(6652):749-53.

24. Vulchanova L, Riedl MS, Shuster SJ, Stone LS, Hargreaves KM, Buell G, et al. P2X3 is expressed by DRG neurons that terminate in inner lamina II. Eur $J$ Neurosci. 1998;10(11):3470-8.

25. Jahr CE, Jessell TM. ATP excites a subpopulation of rat dorsal horn neurons. Nature. 1983;304(5928):730-3

26. Li P, Calejesan AA, Zhuo M. ATP P2X receptors and sensory synaptic transmission between primary afferent fibers and spinal dorsal horn neurons in rats. J Neurophysiol. 1998;80(6):3356-60.

27. Vongtau HO, Lavoie EG, Sévigny J, Molliver DC. Distribution of ectonucleotidases in mouse sensory circuits suggests roles for nucleoside triphosphate diphosphohydrolase-3 in nociception and mechanoreception. Neuroscience. 2011;193:387-98.

28. Hugel S, Schlichter R. Presynaptic P2X receptors facilitate inhibitory GABAergic transmission between cultured rat spinal cord dorsal horn neurons. J Neurosci. 2000;20(6):2121-30

29. Rhee JS, Wang ZM, Nabekura J, Inoue K, Akaike N. ATP facilitates spontaneous glycinergic IPSC frequency at dissociated rat dorsal horn interneuron synapses. J Physiol. 2000;524(Pt. 2):471-83. 